\title{
Jamu Brand Indonesia: Consumer Preferences and Segmentation
}

\author{
Bulan Prabawani \\ Department of Business Administration \\ Social and Political Faculty, Diponegoro University \\ Jl. Prof. Soedarto, SH Tembalang, Jawa Tengah, Indonesian
}

\begin{abstract}
Indonesia is one of the countries that develop traditional herbal medicine, which is called Jamu. However, Jamu is consumed by the poor. Meanwhile, the rich prefer to use modern health treatment. In addition, there is no sufficient confident of people to consume Jamu as their main medical treatment. Hence, identification of potential consumer of Jamu from demographic characteristics and exploration of consumer preferences of Jamu according to the market segments in Indonesia is important for herbal medicine industry to develop a consumer-based marketing strategy. Cramer's Vtest statistical test was used for the analysis of 183 data survey. The findings are consumers of Jamu assumed that Jamu is cheap, easy to obtain, have no side effects, natural, and safe to be consumed. But, they considered herbs as an alternative medicine or therapy, and even as the last resort. Jamu is potential to be developed by product and pricing differentiation, and packaged as a product that emphasizes value with halal certification. In addition, the classification of Jamu as Phytopharmacy has not affected consumer purchasing decisions as it has not been included in the health care system. For middle up segments, Jamu needs a strong brand using English language and required medical professionals as an advisor.
\end{abstract}

Keywords: Jamu, consumer preference, segmentation, marketing strategy.

JEL Classification: M11, M30, M31.

\section{INTRODUCTION}

In its history, Jamu (Indonesian traditional herbal medicine) has been used by the royal family to enhance fitness, to cure ailments, and to maintain beauty (Zuraina et al., 1990 in Limyati \& Juniar, 1998; Stevensen, 1999). Today, Jamu is consumed as complementary and alternative medicine (CAM) (Nissen \& Evans, 2012), therapy, and even to treat severe conditions such as kidney failure and diabetes (Tuschinsky, 1995). In addition, Jamu provides plenty of iron, of which deficiency is a major issue in Indonesia in relation to the role of iron in productivity, child's growth, immunity, and pregnancy health (Kodyat, Kosen, \& De Pee, 1998)

Jamu Brand Indonesia was initiated by President Susilo Bambang Yudhoyono on May 27th, 2008 (Purwaningsih, 2013). The government of Indonesia has also requested the UNESCO to establish Jamu as one of the world cultural heritage (Maruf, 2007), with "Jamu" as the term used instead of "herbal medicine". This branding is seen as a distinguishing mark as herbal medicine is known not only in Indonesia, but also in Malaysia, China, and India. In Malaysia, Jamu is known as Malay phytopharmaceuticals. These herbal medicines have also been used for decades and generations in Malaysia (Tuschinsky, 1995), as self-medication. Suprana (2014), a renowned humanist and Jamu business owner in Indonesia, emphasizes the importance of the term Jamu as a brand instead of herbal medicine in that the word shows serves as the cultural identity of an Indonesian product, much like Batik, Angklung, and Tari Saman, without 
reducing the commercial value of the product.

Market acceptance towards Jamu product from Indonesia has been showing positive trends. On a national scale, Jamu product sales rose $120 \%$ in the last 5 years, from 5 trillion rupiah in 2006 to 11 trillion rupiah in 2011, and to 20 trillion rupiah in 2014, of which 2,5 trillion is obtained from export sales (INFARKES, 2013). KADIN (Indonesian Chamber of Commerce and Industry) recommends Jamu as flagship industrial cluster which driving job creation and reducing poverty rate on the basis of local wisdom (Muslimin et al., 2009). This positive trend is attributed towards the "back to nature" preference adopted by the global community in personal healthcare (Hill \& Howell, 2014). Compared to the conventional medicines, Jamu is more affordable, more readily available, and has fewer side effects (Muslimin et al., 2009). However, many people consider Jamu is not medicine, even though herbal medications can be combined with modern medicines to add therapeutic effects. Even without additional chemical substances, Jamu, which is already classified as Phytopharmacy, may be considered equal with synthetic or chemically enhanced medicines (Dean \& McGuire, 2005).

The Indonesian government has shown its commitment to support Jamu industry up to the point where Jamu has now become an economic pillar for the nation. One exemplary effort comes from the Ministry of Agriculture with the establishment of Spices and Jamu Centre, a hub for information, marketing and education for Jamu (Balittro, 2012). Jamu companies as major players in the development of Jamu also continuously seeks to expand its market, with prime examples such as Ny Meneer selling its products in Malaysia and Vietnam (Amirullah, 2014), Borobudur intensifying its media campaign (Kurniawan, 2015), and Sido Muncul developing standardized Jamu products as an effort to penetrate global market particularly in Malaysia, Australia, Europe, and the US, along with product differentiation by offering various flavours (Prima Wirayani, 2015). However, Charles Saerang and Jaya Suprana, both influential Jamu businessmen in Central Java, believe that much more exploration of the potential of traditional Indonesian Jamu has to be made before the industry reaches its full potential (Muslimin et al., 2009).

Stevensen (1999) finds Jamu has only been used by the poor and those with low income in Indonesia for the past decade. High health care cost is one of the main causes of this phenomenon. On the other hand, wealthy Indonesians often seek medical care outside of the country such as Singapore, to get medical care with better quality. It can be concluded that Indonesian consumers do not possess trust to the poorly managed and packaged Jamu. So far there has been no sense of pride in Indonesians for consuming Jamu products (Pos Sore, 2015). In addition, foreign herbal medicines take up the limelight of alternative medicines, which can be attributed to the lack of promotion and information of the potency of Indonesian Jamu (Elfahmi, Woerdenbag, \& Kayser, 2014), while intensive campaign of Mastin, a mangoesteen peel extract product, is proven to capture the attention of many consumers (Kurniawan, 2015).

Despite all these challenges, however, Jamu products keep showing positive trends in sales. Still, the figure is away from where many Jamu industrialists hope for, considering the vast potency of Jamu as a genuine Indonesian product to be developed and be internationally recognized. Also, there have not been many studies conducted on the Indonesian consumer preference towards Jamu. In the past, studies on Jamu mainly concerns on its medical potency or its relationship with the wealth of floral specimens in Indonesia. Some studies in the past also made efforts to upgrade herbal medications not only as Jamu therapy but also as standardized practice, as far as going for Phytopharmacy. All the while, exploration of consumer preference towards Jamu is just as essential to conduct the appropriate marketing mix, which involves among others the required product/service, price, place, and promotion. Therefore, this research aims to; first, identify consumer preference towards Jamu according to 
social demographic characteristics in order to map market potential of Jamu. This map of market potential will be useful to discover alternative market shares for Jamu products. Secondly, this research aims to discover consumer preference towards Jamu according to market share in an effort to identify the desired consumers' treatments which will encourage them to use Jamu instead of modern or foreign herbal medications.

\section{Types of Indonesian Jamu}

\section{LITERATURE REVIEW}

Jamu in its many variants is identified academically and globally as herbal medicine, phytotherapy, botanical medicine, medical herbalism, and herbalism (Nissen \& Evans, 2012). In Indonesia, Jamu is classified based on its production process, user claims, and all of which is regulated in Decree of the Head of Indonesian Drug and Food National Agency number HK.00.05.4.2411 on Fundamental Regulation on Classification and Designation of Indonesian Natural Medicines. According to the regulation, Jamu is grouped into traditional Jamu, standardized herbal medicine, and Phytopharmacy (Badan Pengawas Obat dan Makanan, 2004).

Traditional Jamu products must meet safety criteria as set out in the existing regulations, go through the empirical test on its claims of efficacy, and must adhere to quality assurance standards. The efficacy and safety of traditional Jamu are empirically confirmed when the recipe has been used for generations. Standardized herbal medicines have to fulfill safety requirements according to present regulations, be tested scientifically/pre-clinically for claims of efficacy, and adhere to specific standards in terms of ingredients used in the end-product. Hence, standardized herbal medicine needs to fulfill quality assurance standards through a pre-clinical test such as toxicity test (safety), dosage approximation, pharmacodynamics test (efficacy) and teratogenicity test (safety towards pregnancy). All the requirements must be met by Jamu of Phytopharmacy category, with efficacy claims clinically tested, and its ingredients are in accordance with recognized standards, as well as meeting all the quality assurance requirements (Badan Pengawas Obat dan Makanan, 2004).

\section{The Development of Jamu}

Commercial Jamu sales began with Jamu gendhong, which is believed to be a production surplus of family medication. Jamu gendhong or Jamu women commonly have no label, are sold in liquid form, and have been used for years and generations, particularly in Java (Sri Zuraina, Sri Harti, Emi Sukarti, 1990 in Limyati \& Juniar, 1998). To name some of the products of Jamu gendhong are beras kencur, cabe puyang, gepyokan, pahitan, and sinom.

There are at least three known ways of producing Jamu gendhong, namely; boiled; dried and ground, sold in powder; and ground, boiled, and simmered into extract (Limyati \& Juniar, 1998; Tuschinsky, 1995). Another variant of traditional Jamu is made only by sun drying (Tuschinsky, 1995). Research by Limyati and Juniar (1998) found that all samples of Jamu gendhong do not meet standards, and are contaminated by Coliform (due to poor hygiene), also are infested with fungus (due to poor storage) and S. Aureus (due to poor hygiene of producing personnel and production equipment). Moreover, Salmonella Typhus and Paratyphoid (attributed to typhoid fever in humans) are also found in the samples. Consumers doubt in consuming Jamu is not without reasons. One of those reasons is the quality of the raw material and end products which are questionable at best. Zhang, Wider, Shang, Li, and Ernst (2012) listed an inventory of research on herbal medicine and compiled evidence of contamination of heavy metal in the herbal medicines inquired. In addition to that fact, herbal medicines, which are lauded for its chemical additive-free nature, are proven to still contain a chemical additive in their contents. 
Since the $20^{\text {th }}$ century, however, Jamu began to be sold more intensively and began to be known as modern Jamu industry. The rise of modern Jamu in Indonesia began with brands like Jamu Jago, Nyonya Meneer, and Air Mancur. In 1995 alone, there were 350 big and small business companies listed as the producer of Jamu in Indonesia. More Jamu companies participated in the business as demands both local and export of Jamu increases. Today, Jamu is freely sold in the form of liquid and powder, as well as tablet, pill, and tonic (Tuschinsky, 1995). Most Jamu companies operate in accordance with proper industrial standards and perform a clinical test on their products, thereby putting their brands in the level of Phytopharmacy, or similar to modern medicines.

\section{Preference}

Preference has defined the disposition of an individual towards an object which is commonly reflected in explicit decision-making processes (Bettman, Luce, \& Payne, 2006). In other words, preference is one's feeling of like or dislike towards an object. Preference is dynamic in nature, which means that it changes along with a shift in value, education level, perception, time, situation, and lifestyle of the respective individual.

In relation to preference towards Jamu, Jamu is perceived to have various efficacy, are divided into a number of quality classifications, and are produced by a number of companies which are perceived to make an effort to create certainty among their consumers. So far, efforts in crosscorporation strategy integration to create an image as an Indonesian brand are still found to be very limited. Therefore, preliminary studies need to be conducted to identify the consumer groups of Jamu and the preferences prevalent in each group or, in other words, market segmentation.

Social demographic characteristics are features which describe differences in population based on age, sex, occupation, education, religion, income, family type, marital status, and geolocation. With social demographics mapping, companies can identify market targets. Social demographic information also reflects the current trends. Demographics can also be used to observe changes in demands of various products and to evaluate marketing campaigns. After the market has been grouped based on each demographic characteristics, then the preference of each group can be identified. As an example, the identification consumer group with a preference towards Jamu with Arabic label, with reference to Tuschinsky (1995) who discovers that, for a market in Malaysia, it is suggested that producer labels their products with Islamic-themed packaging, orthography, or visuals, as opposed to the Javanese-themed ones. This preference is attributed to the faith-oriented view of the Muslim community which asserts stronger influence over the culture of the country of origin of the product.

According to Little (2009), six preference criteria for Jamu products are obtained from research in several industrious countries, all of which can enrich the consumer preference in each of the segments. These criteria are the efficacy claim that Jamu can relieve symptoms of sickness and that Jamu is perceived to give side effects. Another criterion is based on the relationship formed between clients and practitioner/professionals in herbal medicines, as well as the minimum effect that Jamu have on daily activities. In western countries, continuous use of herbal medicines is attributed to a strong bond between practitioners or professionals and their consumers. The practitioners retain their consumers by putting special attention to the need of consumers to be heard (Nissen \& Evans, 2012). Little (2009) adds that clients seeking herbal medication treatments also enjoys chatting with other clients. 
Forming brand equity in order to encourage the local community to consume Jamu as alternative medicines, Thai government applies community-oriented approach and clinicoriented approach. Both approaches are applied considering Jamu is often sought out as medication whenever modern pharmacy is deemed insufficient by consumers in Thailand. This research finds that the adoption of clinic-based approach is more successful in Thailand private hospitals than in government-run hospitals. In addition, community-based approach is more effective in self-initiative consumption of medications, compared to initiatives from doctor's prescriptions or other professionals' suggestions. Professionals are found to have a more significant role in the consumption of Jamu in clinic-based approach. Therefore, the government needs to take a role in encouraging the use of Jamu in healthcare (Elfahmi et al., 2014). The experience from Thailand shows that recommendation is one of the key elements in promotion as a part of a marketing mix, which plays a significant part in marketing strategy compared to, for example, price point or product quality.

In modern Jamu industry, various promotional campaigns through advertisements in printed and broadcast media have been intensively pursued. Even so, word-of-mouth (WOM), which is a type of recommendation, is a part of promotional media which still possesses a significant influence (Tuschinsky, 1995). So far, Jamu producer companies have been using house-to-house seller, in which the reseller also acts as a healthcare or beauty consultant. Ready-to-drink Jamu counters are vastly spread all over urban areas in Indonesia and Malaysia. In this scheme, house-to-house sellers, resellers, and ready-to-drink Jamu counters take up the role of Jamu consultants for end-consumers. However, product knowledge of these people is perceived to be limited on what is written in the packages of the Jamu they sell. On the other hand, consumers expect more information from the Jamu products that they consume (Tuschinsky, 1995).

\section{METHODOLOGY}

This research uses positivism paradigm with survey so that findings can be generalized (Cooper, D. R., \& Schindler, 2013) as Collis, J., \& Hussey (2009, p. 76) say that a survey has the purpose of collecting "primary and secondary data from a sample with a view to analyze them statistically and to generalize the results to a population". In this research, the survey aimed to obtain primary data of the Jamu consumption behaviour of Indonesian. In addition, the survey included questions to gather both descriptive and analytical data. Descriptive questions were used, particularly to assess consumers' perception and comprehension of Jamu about the price, packaging, side effects, and also the classification. Analytical survey questions determined the relationship between consumers' segmentation and their perception and comprehension towards Jamu.

This is an exploratory study considering that studies relevant to the Jamu consumption behaviour, particularly in Indonesia, are limited. Most papers on Jamu mainly discuss the exploration of various botanical products in Indonesia for healthcare. Meanwhile, social studies concerning the consideration and how consumers consume Jamu as alternative medication are few. This study can be a representation of Indonesian consumers towards Jamu referring to social demography segmentation.

The questions were measured in the form of grades or rates by a Likert scale using 6 scales, ranging from strongly disagree (scale number 1 ) to strongly agree (scale number 6). Thus, referring to Cooper and Schindler (2013, p. 312), the data were included as an interval scale because there is "classification, order, and distance, but no natural origin". An even number was chosen as Mitchell (1999 in McGorry, 2000) mentions that Asian respondents tended to prefer the middle value of an odd-numbered scale. In addition, according to Kulas \& 
Stachowski (2009, p. 489), the middle response has the potential to be the "dumping ground", thereby showing the respondents' "uncertain, indifferent or ambivalent response orientations".

The population of this research is actual and potential Jamu consumers from all across social demographic strata in Indonesia, which the views were collected by convenience sampling. Self-administered questionnaires are distributed by door-knocking, along with an online survey which is widely distributed to respondents through Google form during November 2015. Data analysis is performed by basic statistics of frequency distribution and Cramer's Vtest to identify the relationship between variables involved for 2-by-2 or more tables on nominal data (Pallant, 2007). In addition, to gain goodness criteria of the data collection, the respondents were those who have a minimum age of 17 years old and must be those who have a role in decision-making related to health and stamina issues in their respective families. This study involved 183 samples as according to Fink (1995), in order to obtain standard error of less than 10\%, the sample size has to be more than 100 units, while Hair, J. F., Black, W. C., Babin, B. J., Anderson, R. E., \& Tatham (2006) mention that to increase precision, there should be a sample of between 150 to 200 .

\section{FINDINGS}

General description of a respondent is made to understand the characteristic of the respondent, who have given answers to the questions listed in the questionnaires. That the answers given by a respondent are affected by his social and economic background is always a possibility. This brief description of a respondent includes the identification of age, education, religion, and other social statuses.

The respondents participating in this research comprise of 183 Indonesian nationalities that are mostly Muslim and come from Javanese ethnicity. Respondents come from various age ranges, from 18 to more than 61 years old, which are then grouped into five age ranges. The majority of the respondents are women, married, and holding a university degree or similar qualification. Respondents with more than IDR 2.5 million in a month make up $56.3 \%$ of the population. The detail of respondents' demographics profile is the following:

Table 1 Demographics profile of the respondents

\begin{tabular}{l|l|l|l}
\hline Demographics & Categories & $\begin{array}{l}\text { Frequen } \\
\text { cy }\end{array}$ & $\mathbf{\%}$ \\
\hline Age & $\leq 30$ y.o & 72 & 39,3 \\
\hline & $41-50$ & 39 & 21,3 \\
\hline & $31-40$ & 36 & 19,7 \\
\hline & $51-60$ & 25 & 13,7 \\
\hline Religion & $\geq 61$ y.o & 11 & 6,0 \\
\hline & Muslim & 161 & 88,0 \\
\hline Race & Non-Muslim & 22 & 12,0 \\
\hline Marital status & Javanese & 148 & 80,9 \\
\hline Education & Non-Javanese & 35 & 19,1 \\
\hline & Married & 111 & 60,7 \\
\hline Spending & less than higher degree & 80 & 39,3 \\
\hline & higher degree & 103 & 43,7 \\
\hline & $\leq$ Rp2,5 mill & 80 & 43,7 \\
\hline & $>$ Rp 2,5 - 5 mill & 68 & 37,2 \\
\hline & $>$ Rp 5 - 10 mill & 33 & 18,0 \\
\hline & & &
\end{tabular}




\section{Consumer Preference}

\begin{tabular}{l|l|l|}
$>$ Rp 10 mill & 2 & 1,1 \\
\hline
\end{tabular}

The majority of Jamu consumers in Indonesia perceive Jamu prominently as an affordable product $(95.6 \%)$ and widely available $(89,1 \%)$, with both perceptions scoring at an average of 5.1. This means that Jamu is perceived as convenience goods in Indonesia. Consumers also perceive Jamu as a natural product (93.4\%). On the other hand, the perception that Jamu is safe to consume, without side effects and the chemical additive is not as prevalent as that of the availability and affordability of Jamu. As many as 78,7\% of consumers believe that Indonesian Jamu is safe to consume, $63.9 \%$ of consumers think that Jamu is without side effects, and only $57.9 \%$ of consumers believe that Jamu is made without chemical additives, scoring a mean of 3.7.

As a consequence, there is reluctance among the consumers to use Jamu as a primary choice for medication, leading them to opt for a modern pharmacy to help cure sickness or to be used in therapy. This research discovers that only $62.1 \%$ of consumers who use Jamu as a primary choice for medication. As a treatment for more severe illnesses, only $65.6 \%$ consumers choose Jamu as an alternative medication. There is even tendency to make Jamu as a last resort in medication, as stated by $67.8 \%$ of consumers.

Even when it is found that there are many consumers who make Jamu as their first choice of medication, the finding is not surprising since the majority of the respondents involved in this research, as much as $80.3 \%$, spend S IDR 5 million monthly. This finding is consistent with what Stevensen (1999) found which states that from a decade ago until today, Jamu is a medication mainstay for people with little or no income at all. In addition, Jamu consumers with considerably higher income only use Jamu to treat mild sickness.

Reference or media group perceived giving the most significant influence on Jamu consumption in Indonesia by $62.6 \%$ of the consumers are professionals, namely medical doctors and healthcare consultants. In addition, friends and colleagues are also perceived to influence the consumption behavior of Jamu.

This research finds that almost all Jamu consumers in Indonesia, as many as 95\%, prefer to consume Jamu with the halal label, even those who do not adopt Islam as their religion. On the other hand, a citation from the sunnah book on the Jamu package is not a prominent preference for consumers. Another non-prominent preference determinant is the Jamu brand. Consumers do not seem to show a strong preference for specific Jamu brands, such as Arabic, Indonesian, or English branding of the product. As many as $80.9 \%$ of the consumers even disagree with Arabic branding as a preference and choose Jamu as the brand instead. Consumers also do not seem to show a preference for modern packaging. $88.5 \%$ of consumers do not make foreign Jamu brand as a preference, with a mean score of 2.0. In detail, the Indonesian consumers' perception, behaviour, reference, and preference is the following: 
Table 2 Consumers' perception, behaviour, reference, and preference

\begin{tabular}{|c|c|c|c|c|}
\hline Indicator & Disagree & Agree & $\%$ & Mean score \\
\hline \multicolumn{5}{|c|}{ Perception } \\
\hline Cheap & $4.4 \%$ & $95.6 \%$ & $100 \%$ & 5,1 \\
\hline Easy to obtain & $10.9 \%$ & $89.1 \%$ & $100 \%$ & 5,1 \\
\hline Natural & $6.6 \%$ & $93.4 \%$ & $100 \%$ & 4,8 \\
\hline Safe & $21.3 \%$ & $78.7 \%$ & $100 \%$ & 4,4 \\
\hline No negative effect & $36.1 \%$ & $63.9 \%$ & $100 \%$ & 4,0 \\
\hline $\begin{array}{l}\text { No chemical } \\
\text { substance }\end{array}$ & $42.1 \%$ & $57.9 \%$ & $100 \%$ & 3,7 \\
\hline \multicolumn{5}{|c|}{ Behaviour } \\
\hline Main medicine & $38.8 \%$ & $61.2 \%$ & $100 \%$ & 3,8 \\
\hline Alternative medicine & $34.4 \%$ & $65.6 \%$ & $100 \%$ & 3,9 \\
\hline Last resort & $32.2 \%$ & $67.8 \%$ & $100 \%$ & 3,9 \\
\hline \multicolumn{5}{|c|}{ Reference group } \\
\hline Friend & $38.8 \%$ & $61.2 \%$ & $100 \%$ & 3,5 \\
\hline Waiter & $45.9 \%$ & $54.1 \%$ & $100 \%$ & 3,2 \\
\hline Professional & $37.2 \%$ & $62.8 \%$ & $100 \%$ & 3,7 \\
\hline Social media & $60.7 \%$ & $39.3 \%$ & $100 \%$ & 2,8 \\
\hline Commercial ad. & $54.6 \%$ & $45.4 \%$ & $100 \%$ & 3,0 \\
\hline \multicolumn{5}{|c|}{ preference } \\
\hline Halal & $4.4 \%$ & $95.6 \%$ & $100 \%$ & 5,4 \\
\hline Prophet sunnah & $59.6 \%$ & $40.4 \%$ & $100 \%$ & 3,2 \\
\hline $\begin{array}{l}\text { Foreign herbal } \\
\text { medicine }\end{array}$ & $88.5 \%$ & $11.5 \%$ & $100 \%$ & 2,0 \\
\hline Modern packaging & $56.8 \%$ & $43.2 \%$ & $100 \%$ & 3,5 \\
\hline Arabic brand & $80.9 \%$ & $19.1 \%$ & $100 \%$ & 2,6 \\
\hline Indonesian brand & $55.2 \%$ & $44.8 \%$ & $100 \%$ & 3,3 \\
\hline English brand & $54.1 \%$ & $45.9 \%$ & $100 \%$ & 3,5 \\
\hline
\end{tabular}

Only 55\% of Indonesian Jamu consumers are aware that Jamu products are grouped into several classifications, with each classification logo is printed on the packaging. However, most consumers do not know of the existing classifications, the form of the logo used for each classification, especially those belonging to Phytopharmacy Jamu. Therefore, consumers do not take Jamu classification into consideration when consuming Jamu. Although consumers are not aware of Jamu classifications and know the logo of the classifications, the majority of them believe that traditional Jamu and standardized herbal medicine is chemical additive-free.

Other than product attribute preference, Jamu consumers in Indonesia do not show a strong preference for Jamu products from a certain country of origin. Not one preference for each country of origin criterion obtains more than 50\% mark from the consumers. So much so that only $19.1 \%$ of the consumers make Arabic Jamu as their preference. Today, the most consumed Jamu products are modern Jamu Tolak Angin and Jamu gendhong, such as Beras Kencur and Kunir Asem. This research finds a trend that Jamu consumers are not aware of Jamu classification, nor do they consider those classifications in making the decision to consume Jamu. Only $40 \%$ to $55 \%$ of all the consumers are aware of Jamu classifications and the different logos representing those classifications. Almost all of the consumers know the logo for traditional Jamu, yet only $24.6 \%$ and $15.3 \%$ of the consumers know the logos for standardized herbal medicines and Phytopharmacy respectively. There is an interesting finding in which consumers perceive the higher classification of a Jamu is, the more chemical additives in its contents. 
Table 3 Consumers comprehension of Jamu classification and chemical substance

\begin{tabular}{|c|c|c|c|c|}
\hline Indicator & Disagree & Agree & $\%$ & Mean score \\
\hline \multicolumn{5}{|c|}{ Classification } \\
\hline Number of classes & $59,6 \%$ & $40,4 \%$ & $100 \%$ & 3,0 \\
\hline Logo of classes & $44,8 \%$ & $55,2 \%$ & $100 \%$ & 3,4 \\
\hline Logo of traditional Jamu & $51,4 \%$ & $48,6 \%$ & $100 \%$ & 3,5 \\
\hline Logo of standardized herbal & $75,4 \%$ & $24,6 \%$ & $100 \%$ & 2,6 \\
\hline Logo of Phytopharmacy & $84,7 \%$ & $15,3 \%$ & $100 \%$ & 2,3 \\
\hline Classes consideration in the consumption & $51,4 \%$ & $48,6 \%$ & $100 \%$ & 3,4 \\
\hline \multicolumn{5}{|c|}{ Chemical substance } \\
\hline Traditional Jamu without chemical & $39 \%$ & $61 \%$ & $100 \%$ & 3,8 \\
\hline Standardized herbal without chemical & $42 \%$ & $58 \%$ & $100 \%$ & 3,6 \\
\hline Phytopharmacy without chemical & $56 \%$ & $44 \%$ & $100 \%$ & 3,2 \\
\hline
\end{tabular}

In determining their purchase or consumption of Jamu products, consumers directly and indirectly obtain their reference from colleagues, mass media, social media, as well as other reference groups. For Jamu companies, identifying the most potential media as sources of product information and recommendation for consumers is very important, so that the companies can maximize the role of such reference media in marketing their products.

Table 4: Consumers' reference groups

\begin{tabular}{|c|c|}
\hline Variable & Cramer's V \\
\hline Age vs Friend/colleague & ,230* \\
\hline Age vs Shop waiter & ,240* \\
\hline Age vs Professional &, $223 *$ \\
\hline Age vs Social media & ,236* \\
\hline Age vs Commercial ad & ,248* \\
\hline Religion vs Friend/colleague &, 147 \\
\hline Religion vs Shop waiter &, 123 \\
\hline Religion vs Professional &, 134 \\
\hline Religion vs Social media &, $229 *$ \\
\hline Religion vs Commercial ad &, 172 \\
\hline Spending vs Friend/colleague &, 145 \\
\hline Spending vs Shop waiter &, 187 \\
\hline Spending vs Professional & ,199 \\
\hline Spending vs Social media & ,392* \\
\hline Spending vs Commercial ad &, $224 *$ \\
\hline Education vs Friend/colleague &, 177 \\
\hline Education vs Shop waiter &, 191 \\
\hline Education vs Professional & ,219* \\
\hline Education vs Social media &, 175 \\
\hline Education vs Commercial ad & ,196 \\
\hline
\end{tabular}

This research has found that, first, there are significant differences in the age group to make friend/colleague, shop waiter, professional, social media, and commercial advertisement as media references of Jamu consumption. Second, there is a significant difference in the religion group to make social media as media references of Jamu consumption. Third, there are significant differences in the spending group to make social media and commercial 
advertisement as media references of Jamu consumption. Fourth, there is a significant difference in the education group to make professional as media references of Jamu consumption.

\section{Consumer Segmentation}

In this research, Jamu consumers in Indonesia are grouped based on their demographic aspects, namely age, religion, education, income, ethnicity, marital status, and sex. This research identifies how the difference in each demographic class influences preferences in a certain attribute of Jamu products.

According to their age, consumers from different age groups have their own preferences in specific Jamu products. Older consumers prefer Jamu with Indonesian brand over those with Arabic brand. In addition, consumer age and preference in Indonesian Jamu brand show lateral correlation. On the other hand, consumer age and awareness of the 3 classifications of Jamu shows inverse correlation, with older consumers being less aware of and do not take these classifications into consideration when purchasing and consuming Jamu products. Different preferences are also found among Muslim and Christian consumers and Catholic consumers. Muslim and Christian consumers have a higher preference in Jamu with halal label compared to those with Catholic as religion. However, citations from the sunnah book do not seem to give significant influence towards the preferences of Jamu consumers across the segments. Only Muslim consumers show positive preference in Jamu with a citation from the sunnah book on its package.Educational background of consumers does not show significant influence towards their consumption of Jamu products. However, education level of consumers shows a positive relationship with awareness of the consumers of Jamu classifications and their logos. Income level does not seem to influence consumer preference in Jamu products packaging. There is a positive tendency, however, that the higher the income of the consumers, the more likely that they prefer to consume Jamu with modern packaging and Indonesian brand.

Women have a stronger perception that Jamu in Indonesia is chemical additive-free. Contrary to this fact, more men are shown to consider Jamu classification prior to product purchase or consumption than women. Consumers who were married or are currently married prefer Indonesian Jamu, have no significant preference in Jamu package with sunnah citation, and tend to purchase Jamu with modern packaging. On the other hand, these consumers are shown to have low awareness of Jamu classifications and their logos. Therefore, consumers who were or are currently married do not make Jamu classifications and their logos as a preference when purchasing or consuming Jamu products. This following table describes the influence of demographic characteristics towards consumers' perception, behaviour, reference, and preference of Indonesian Jamu. 
Table 4 Cramer's V-test significance

\begin{tabular}{|c|c|c|c|c|c|c|c|}
\hline Perception & $\begin{array}{l}\text { Age } \\
\text { class }\end{array}$ & Religion & Education & Spending & Race & $\begin{array}{c}\text { Marital } \\
\text { status } \\
\end{array}$ & Sex \\
\hline 1. Cheap & $\mathbf{0 , 0 2 3} *$ & 0,526 & 0,118 & 0,263 & 1,000 & 0,154 & 0,053 \\
\hline 2. Easy to obtain & $0,003 *$ & 0,922 & 0,299 & 0,863 & 0,948 & $0,001 *$ & 0,207 \\
\hline 3. No negative effect & $0,031 *$ & 0,423 & 0,099 & 0,393 & 0,811 & $0,030 *$ & 0,259 \\
\hline 4. No chemical substance & $0,005 *$ & 0,196 & 0,358 & 0,267 & 0,720 & $0,024 *$ & $0,014 *$ \\
\hline 5. Safe & 0,661 & 0,490 & 0,059 & 0,151 & 0,780 & 0,470 & 0,831 \\
\hline 6. Natural & 0,203 & 0,142 & 0,970 & 0,503 & $0,000^{*}$ & 0,310 & 0,770 \\
\hline 7. Main medicine & 0,906 & 0,921 & 0,590 & 0,338 & 0,681 & $0,030 *$ & 0,994 \\
\hline 8. Alternative medicine & 0,412 & 0,202 & 0,445 & 0,111 & 0,407 & $0,000 *$ & 0,064 \\
\hline 9. Last resort & 0,309 & 0,898 & 0,593 & 0,237 & 0,523 & 0,262 & 0,592 \\
\hline 10. Foreign herbal medicine & 0,197 & 0,522 & 0,314 & 0,965 & $0,000 *$ & 0,086 & 0,658 \\
\hline 11. Prophet sunnah & 0,377 & $0,000 *$ & 0,853 & 0,286 & 0,686 & 0,095 & 0,144 \\
\hline 12. Halal & 0,643 & $0,001 *$ & 0,709 & 0,667 & $0,000 *$ & 0,363 & 0,065 \\
\hline 13. Modern packaging & 0,381 & 0,679 & 0,159 & $0,006 *$ & 0,886 & $0,027 *$ & 0,095 \\
\hline 14. Arabic brand & $0,006 *$ & 0,198 & 0,437 & 0,672 & 0,955 & 0,490 & 0,747 \\
\hline 15. Indonesian brand & $0,000 *$ & 0,618 & 0,081 & $0,009 *$ & 0,773 & $0,000 *$ & 0,052 \\
\hline 16. English brand & 0,052 & 0,285 & 0,187 & 0,107 & 0,286 & $0,009 *$ & 0,536 \\
\hline 17. Number of classes & $0,000 *$ & 0,666 & 0,076 & 0,260 & 0,588 & $0,001 *$ & 0,141 \\
\hline 18. Logo of classes & $0,000 *$ & 0,121 & $0,024 *$ & 0,569 & 0,974 & $0,000 *$ & 0,187 \\
\hline $\begin{array}{l}\text { 19. Classes consideration in } \\
\text { the consumption }\end{array}$ & $\mathbf{0 , 0 0 5 *}$ & 0,721 & 0,059 & 0,057 & 0,118 & $0,000 *$ & $0,041 *$ \\
\hline
\end{tabular}

*significant

\section{DISCUSSION}

Studies related to consumer preferences are crucial, particularly nowadays, when technological advances have provided consumers with more options of products. At the same time, products and services are getting shorter lifetimes. Moreover, value trade-offs in commerce make preference construction more complex and dynamic (Bettman et al., 2006). In medical world, Jamu is still situated in a less competitive market. Even when there are various product options, one product does not have significant advantage over another. Moreover, low market price of Jamu makes switching cost low. This fact accounts for low consumer loyalty. Despite all that, Jamu companies need to build preferences, since costumer preference is context sensitive, and it is built and is determined by target, cognitive constraints, and experience.

One of the most significant factors in building consumer preference in Jamu is halal product certification, which has been proven as the main indicator for consumers in the purchase and consumption of herbal medicines. This finding is notable since the study of El-bassiouny (2014) shows that today there are as many as one billion Muslims, yet they are still marginalized by limited studies about them. Meanwhile, proper application of marketing strategy promises a significant boost in sales through products which emphasize value and morality, namely halal products (Matin, 2011 in El-bassiouny, 2014). It is interesting to note that preference for halal products is also held by consumers with religion other than Islam. Moreover, Yusuf and Yajid (2015) in their research, which is conducted in five Asian countries, show that there is an increasing awareness of a halal product and its logo. The halal label has become a priority in choosing a product, which is followed by quality, brand, and price factors. 
On the other hand, preference is not always a precursor for purchasing decision. Therefore, producers must understand the cognitive processes which the consumers go through in making their decision. In the Search for Dominant Structure (SDS) theory (Montgomery, 1983 in Crozier \& Ranyard, 1997), when consumers are faced with multiple alternatives, they go through stages of pre-edition, finding a promising alternative, dominance testing, and dominance structuring. In purchasing and consuming Jamu, consumers select one product among the many kinds of Jamu products, they will then narrow down their selection to a number of products which are most relevant.

Jamu products are seen by many Indonesian consumers as convenient goods, which mean consumers do not need high effort and consideration in obtaining the products. Convenience goods do not have strong characteristics which distinguish them from their competing brands (John F. Tanner \& Raymond, 2012). Therefore, Jamu products need to be designed as such that they are widely available, particularly affordable and practically packaged in order to allow high purchase frequency. This is due to the fact that Jamu has had 'crystallized' values (Schuman and Presser 1981 in Bettman, 1999), of which consumers are very familiar with the products or services and value them based on the common assumption of the said products or services. Based on this finding, Jamu classification is not an urgent matter and is a somewhat "wasted" effort.

On the other hand, Indonesian government adopts Indian Ayurveda which includes the use of herbal medicines in healthcare services (Shrivastava, Shrivastava, \& Ramasamy, 2015), and makes classification and enrichment of Jamu into Phytopharmacy, under the management of Department of Healthcare, as an important objective. A government regulation which includes Jamu as primary medication in public health care services and which gives more access to the testing of Jamu and its halal certification is much needed. Moreover, as people gets more and more educated, they demand Jamu companies come up with safe-to-consume Jamu products. It is found that the higher the income of the consumers, the more they desire products with modern packaging. Therefore, Jamu companies can make product differentiation between those for the low-income, middle-income, and high-income consumers as consumers are social groups that undergo dynamic changes (Moss, 2006). In addition, Moss (2006) also states that consumers adapt more easily to new products through differentiation rather than radical change. In light of this finding, Jamu companies may create differentiation on their line of products, in which one product is labeled "better" when compared to the other. Thus, branding takes a crucial place in this effort. When further developed, Jamu will eventually turn into a shopping product from its current perception as a convenience product.

Consumers from middle to high-income groups also tend to choose herbal medicines or Jamu with labels in English. Hence, it is most appropriate that Jamu products intended for lower income consumers are labeled in a local language and be sold at the lowest possible price point. Contrary to the preceding step, products designated for middle to high-income consumers should be offered in a more modern branding and packaging, as it will express images of high-quality, exclusive, and long-lasting products (Moss, 2006). Packaging must always take the utmost concern of Jamu companies, as packages do not only function as product containers, but also determine quality and safety of the product as well as a preventive measure from chemical, biological, and physical damage to the products (Trinetta, 2016). Although the direct consequence of better product packaging is better quality assurance of the products, it also adds the price point of the product. To handle this, Jamu companies may adjust the price point of better-packaged products for appropriate consumers in certain income groups and social class, the products being a status symbol (Moss, 2006), consumers from higher income groups and social class deserve a special treatment. 
Professional advisers in herbal medicines, for instance, are demanded by consumers with higher educational level. These consumers trust the opinion of professionals as reference media, rather than social media and commercial advertisements, particularly for healthcare products. The access to professional advisers is intended so that consumers can comfortably consult in determining which product is suitable for their personal needs. This deserves attention since, in Indonesia, professional consultants in herbal medicines are not commonly found. On the other hand, Jamu depots can still play their role in consulting consumers from the lower income groups. However, depot sellers should have the necessary skills and product knowledge. Depot sellers should not only serve the consumers as far as providing the requested products, but they also need to be aware of and have sufficient knowledge in the variants of the products that they sell.

\section{ACKNOWLEDGMENT}

I would like to thank to Social and Political Sciences Faculty of Diponegoro University for the research funding.

\section{CONCLUSION}

Jamu has been specifically referred to by consumers as an Indonesian product with potential development, considering its vast market and its compatibility with characteristics of many communities. Using the findings in this research, Jamu companies can appropriately make product differentiation according to the perception and preference of the consumers in the proper market segments. Findings in this research can be combined with marketing strategies of Jamu companies so that they can accurately identify a target market and determine the most effective promotional design. However, the development of Jamu industry requires the support from the government, particularly in realizing Jamu consumption as an Indonesian culture. The realization of Jamu consumption as Indonesian culture is expected to increase consumer trust towards Jamu. Jamu is not just as supplements and last resort medications, but as primary medications acceptable in the medical world, not just limited to the poor. Research centre also need to expand their capacity from finding to construct consumer preference.

\section{References}

Amirullah. (2014). Ny Meneer Buat Minyak Telon di Malaysia dan Vietnam (Ny Meneer makes Telon Oil in Malaysia and Vietnam). Tempo.co. Jakarta. Retrieved from https://m.tempo.co/read/news/2014/11/17/090622566/ny-meneer-buat-minyak-telon-di-malaysia-danvietnam

Badan Pengawas Obat dan Makanan. Ketentuan Pokok Pengelompokan dan Penandaan Obat Bahan Alam Indonesia (Classification and Marking of Indonesian Natural Drugs), Pub. L. No. HK.00.05.4.2411 (2004). Indonesia. http://doi.org/10.1017/CB09781107415324.004

Balittro. Rencana Strategis Balai Penelitian Tanaman Rempah dan Obat 2012 - 2014 (Strategic Plan of Spices and Medicinal Plants Research Institute) (2012).

Bettman, J. R. (1999). Measuring Constructed Preferences: Towards a Building Code. Journal of Risk and Uncertainty, 1(3), 243-270.

Bettman, J. R., Luce, M. F., \& Payne, J. W. (2006). Constructive Consumer Choice Processes. In S. Lichtenstein \& P. Slovic (Eds.), The Construction of Preference (pp. 323-341). New York, United States of America: Cambridge University Press.

Collis, J., \& Hussey, R. (2009). Business research: A practical guide for undergraduate\&postgraduate students (3rd ed.). New York: Palgrave Macmillan.

Cooper, D. R., \& Schindler, P. S. (2013). Business Research Methods (12th ed.). Singapore: McGraw-Hill International. 
Crozier, R., \& Ranyard, R. (1997). Cognitive process models and explanations of decision making. In R. Ranyard, W. R. Crozier, \& O. Svenson (Eds.), Decision making: Cognitive models and Explanations (pp. 20-35). London, New York: Routledge.

Dean, A., \& McGuire, T. (2005). Herbal therapies and substance use. Drugs and Alcohol Today, 5(2), 37-39. http://doi.org/http://dx.doi.org/10.1108/17459265200500028

El-bassiouny, N. (2014). The one-billion-plus marginalization : Toward a scholarly understanding of Islamic consumers. Journal of Business Research, 67(2), 42-49. http://doi.org/10.1016/j.jbusres.2013.03.010

Elfahmi, Woerdenbag, H. J., \& Kayser, O. (2014). Jamu: Indonesian traditional herbal medicine towards rational phytopharmacological use. Journal of Herbal Medicine, 4(2), 51-73. http://doi.org/10.1016/j.hermed.2014.01.002

Fink, A. (1995). How to sample in surveys (6th ed.). Thousand Oak, London, New Delhi: SAGE Publications Ltd.

Hair, J. F., Black, W. C., Babin, B. J., Anderson, R. E., \& Tatham, R. L. (2006). Multivariate data analysis (6th ed.). New Jersey: Prentice Hall.

Hill, G., \& Howell, R. T. (2014). Moderators and mediators of pro-social spending and well-being: The influence of values and psychological need satisfaction. Personality and Individual Differences, 69, 69-74.

http://doi.org/10.1016/j.paid.2014.05.013

INFARKES. (2013). Pendampingan bagi Pelaku Usaha Jamu Racikan \& Usaha Jamu Gendong (Business Assistanship for Jamu). Bulletin, V, 3-6. http://doi.org/10.1017/CB09781107415324.004

Kodyat, B., Kosen, S., \& De Pee, S. (1998). Iron deficiency in Indonesia: Current situation and intervention. Nutrition Research, 18(12), 1953-1963. http://doi.org/10.1016/S0271-5317(98)00165-1

Kulas, J. T., \& Stachowski, A. A. (2009). Middle category endorsement in odd-numbered Likert response scales: Associated item characteristics, cognitive demands, and preferred meanings. Journal of Research in Personality, 43(3), 489-493. http://doi.org/10.1016/j.jrp.2008.12.005

Kurniawan, N. F. (2015). Pengaruh Fenomena Iklan Televisi (TVC) Ekstrak Kulit Manggis Mastin Terhadap Persepsi dan Preferensi Khalayak (The Influence of Mastin Skin Mangosteen Television Advertising to Audience Perceptions and Preferences). ISI Yogyakarta.

Limyati, D. A., \& Juniar, B. L. L. (1998). Jamu Gendong, a kind of traditional medicine in Indonesia: The microbial contamination of its raw materials and endproduct. Journal of Ethnopharmacology, 63(3), 201-208. http://doi.org/10.1016/S0378-8741(98)00082-8

Little, C. V. (2009). Simply because it works better: Exploring motives for the use of medical herbalism in contemporary U.K. health care. Complementary Therapies in Medicine, 17(5-6), 300-308.

http://doi.org/10.1016/j.ctim.2009.08.001

Maruf, I. R. (2007). The Protection of Indonesian Indigenous Heritage in The International Conventions and Their Implication Toward Indonesian Law: A Background of Study.

McGorry, S. Y. (2000). Measurement in a Cross-Cultural Environment: Survey Translation Issues. Qualitative Market Research: An International Journal, 3(2), 74-81. http://doi.org/10.1108/13522750010322070

Moss, J. (2006). Personal Preference Indicators. Oklahoma: Center for Learning and Leadership. UCEDD.

Muslimin, L., Wicaksena, B., Setiyawan, B., Subekti, N. A., Sukesi, H., Surachman, H., ... Khaidir. (2009). Kajian potensi pengembangan pasar jamu (Potential Market Study of Jamu). Retrieved from www.kemendag.go.id/files/pdf/2014/01/06/Kajian-Jamu.pdf

Nissen, N., \& Evans, S. (2012). Exploring the practice and use of Western herbal medicine: Perspectives from the social science literature. Journal of Herbal Medicine, 2(1), 6-15. http://doi.org/10.1016/j.hermed.2012.02.001

Pallant, J. (2007). SPSS survival manual : a step by step guide to data analysis using SPSS for Windows (version 10).

Pos Sore. (2015). Kita Harus Bangga Minum Jamu (We must Proud Drinking Jamu). Jakarta. Retrieved from http://possore.com/2015/01/09/kita-harus-bangga-minum-jamu/

Prima Wirayani. (2015). Sido Muncul to double its export revenues. The Jakarta Post. Retrieved from http://www.thejakartapost.com/news/2015/11/12/sido-muncul-double-its-export-revenues.html

Purwaningsih, E. H. (2013). Jamu , Obat Tradisional Asli Indonesia: Pasang Surut Pemanfaatannya di Indonesia. eJKI, 1(2), 85-89. 
Shrivastava, S. R. B., Shrivastava, P. S., \& Ramasamy, J. (2015). Mainstreaming of Ayurveda, Yoga, Naturopathy, Unani, Siddha, and homeopathy with the health care delivery system in India. Journal of Traditional and Complementary Medicine, 5(2), 116-118. http://doi.org/10.1016/j.jtcme.2014.11.002

Stevensen, C. (1999). JAMU: an Indonesian herbal tradition with a long past, a little known present and an uncertain future. Complementary Therapies in Nursing \& Midwifery, 5(1), 1-3. http://doi.org/10.1016/S13536117(99)80062-6

Suprana, J. (2014). Pakai Jamu, Jangan Obat Herbal (Consume Jamu, not Herbal Medicine). Suara Merdeka. Semarang. Retrieved from http://berita.suaramerdeka.com/smcetak/pakai-jamu-jangan-obat-herbal/

Trinetta, V. (2016). Definition and Function of Food Packaging. Reference Module in Food Science, 1-2. http://doi.org/10.1016/B978-0-08-100596-5.03319-9

Tuschinsky, C. (1995). Balancing Hot and Cold - Balancing Power and Weakness: Social and Cultural Aspects of Malay Jamu in Singapore. Social Science Medicine, 41(11), 1587-1595.

Yusuf, E., \& Yajid, M. S. A. (2015). Halal pharmaceuticals and cosmeceuticals from the perspective of higher education. Asian Journal of Pharmaceutical Sciences, 11, 18-19. http://doi.org/10.1016/j.ajps.2015.10.013

Zhang, J., Wider, B., Shang, H., Li, X., \& Ernst, E. (2012). Quality of herbal medicines: Challenges and solutions. Complementary Therapies in Medicine, 20(1-2), 100-106. http://doi.org/10.1016/j.ctim.2011.09.004 